\title{
Government Sectoral Expenditure and Poverty Alleviation in Nigeria
}

\author{
Cordelia Onyinyechi Omodero ${ }^{1}$ \\ ${ }^{1}$ Department of Accounting, College of Management Sciences, Michael Okpara University of Agriculture, Umudike, \\ Umuahia, Abia State, Nigeria \\ Correspondence: Cordelia Onyinyechi Omodero, Department of Accounting, College of Management Sciences, \\ Michael Okpara University of Agriculture, Umudike, Umuahia, Abia State, Nigeria.
}

Received: May 16, 2019

doi:10.5430/rwe.v10n1p80
Accepted: June 14, 2019

Online Published: June 24, 2019

URL: https://doi.org/10.5430/rwe.v10n1p80

\begin{abstract}
Poverty alleviation in the developing countries has been an issue of concern especially in Africa which accounts for two-thirds of the total number of people in the world living in extreme poverty. The World Poverty Clock indicates that half of Nigerian population are dwelling in abject poverty, implying that MDGs agenda seems to be ineffective in Nigeria which is the giant of Africa. Thus, this study examines the role of government sectoral expenditure on poverty alleviation using a secondary form of data covering a millennium period from 2000 to 2017 . The study employs ordinary least squares technique and the regression result indicates that government expenditure on agriculture, building and construction, education and health do not have any significant impact on poverty alleviation in Nigeria. The study therefore concludes that government spending on these key sectors of the economy is insufficient and recommends that more funds should be budgeted to boost these sectors in order to eradicate the scourge of poverty in the country.
\end{abstract}

Keywords: government expenditure, poverty alleviation, agriculture, education, health

JEL Classification: H50, H51, H52, H54, I30.

\section{Introduction}

Forecasts by the World Poverty Clock which was gathered by Brookings Institute, revealed that more than 643 million people across the universe live in extreme poverty and about two-thirds of the total number is attributable to Africa (Adebayo, 2018). Based on the data captured by the World Poverty Clock in 2018, top 10 African countries with the largest number of people living in extreme poverty include: Zambia (9.5 million), South Sudan (11.4 million), South Africa (13.8 million), Uganda (14.2 million), Kenya (14.7 million), Mozambique (17.8 million), Tanzania (19.9 million), Ethiopia (23.9 million), Democratic Republic of Congo (60.9 million) and Nigeria (86.9 million) people living in abject poverty (Kazeem, 2018). Thus, Nigeria with a population of about 180 million people equally has about $50 \%$ of its population living in extreme poverty, this is indeed a reflection of the highest poverty level globally. It is also believed that half of the country's population or about 87 million Nigerians live on less than 1.90USD per day, which invariably implies that Nigeria has surpassed India in poverty rating owing to the large number of people living in extreme poverty (Adebayo, 2018). However, to achieve the new universal poverty reduction objective, it requires not just growth, but growth that is combined with distributional modifications that actually decrease poverty by themselves (Anderson, D’Orey, Duvendack \& Esposito, 2018).

One of the Millennium Development Goals (MDG) of Nigeria was to eradicate poverty or reduce it to a barest minimum by 2015 , but the alarming rate of increase in poverty level in the country shows that, realizing this goal even in the nearest future is still far-fetched. Following the MDGs implementation, the United Nations Department of Economics and Social Affairs (UNDESA, 2015) reported that about 1 billion people around the world have been taken out of poverty. In Nigeria, efforts are made to alleviate poverty in the country following the MDGs agenda, but in 2018, Nigeria was declared the world headquarters for extreme poverty (Atiku, 2018). According to Sanusi (2018), the richest man in Africa is from Nigeria and yet Nigeria is the Poverty Capital of the World. The margin of inequality between the rich and the poor in Nigeria is very wide, coupled with lack of infrastructures in the rural areas and migration problems caused by search for greener pastures in other continents by the Nigerian citizens. Sanusi (2018) posits that the problem has always been mismanagement of resources and misplacement of priorities. Funds that should be spent on education, power and establishment of industries in order to create jobs, are recklessly 
misused, hence the migration crisis that has caused the lives of millions of Nigerian youths. Consequently, instead of achieving the MDGs, Nigeria is presently referred to as the World's Poverty Headquarters (Sanusi, 2018). The above background has necessitated this study and it is focused on determining the role of government sectoral expenditure in poverty alleviation in Nigeria.

\section{Literature Review}

\subsection{Conceptual Framework}

This study concentrates on the impact of government sectoral expenditures on poverty alleviation in Nigeria. The conceptual framework below portrays how government spendings on agricultural sector, building and construction, education and health sectors influence per capita income which reflects the well-being of the nation and the level of poverty reduction in the country.

\section{Independent variables}

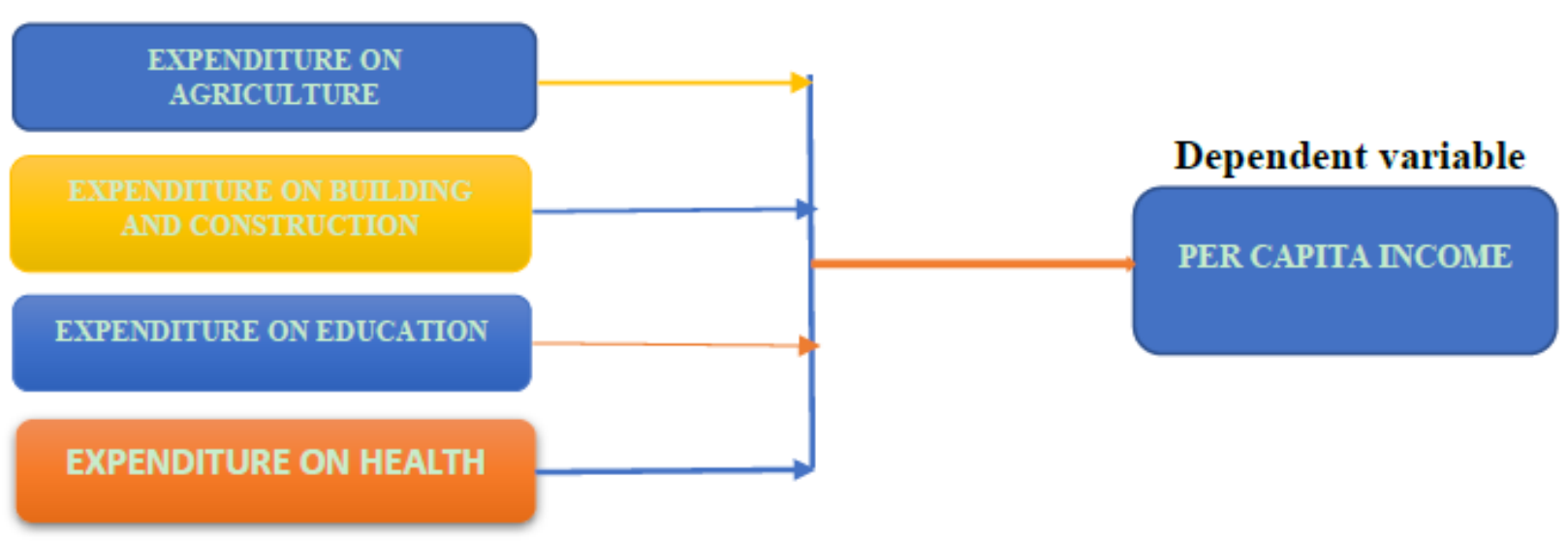

Figure 1.The conceptual model of government sectoral expenditure and per capita income

Source: Author's Desk Research, 2019

\subsubsection{Government Expenditure, Economic Growth and Poverty Alleviation}

Government spending is a potential means of achieving economic growth and reducing poverty through increase in the overall economic performance, human capital development and ensuring that transaction costs are minimized (Wilhelm \& Fiestas, 2005). Public spending can favourably influence economic growth and alleviate poverty through infrastructural provisions and social services (Asghar, Hussain \& Rehman, 2012). Government expenditure is defined as the costs incurred by the government in executing its function especially in the area of providing public goods and services (Ogboru, Abdulmalik \& Park, 2018; Omodero \& Dandago, 2019). In other words, government expenditure which is also referred to as public spending is shown in the budgets which indicate how much will be spent and the revenue sources which involve taxation and other government sources of income (Everett, 2011). Government expenditure is usually categorized as recurrent and capital expenditure (Ogba, 2011). The concept of government expenditure states that public spending ordinarily should enhance economic growth through job creation, reducing rate of unemployment, business expansions through provision of infrastructures and expansion of local markets. These are poverty alleviation measures which are covered under the concept of government expenditure. Asghar et al. (2012) posit that increased government investments in sectors such as health, education, agriculture and social amenities can alleviate poverty, reduce transaction costs as well as increasing the nation's human capital capacity. Dahmardeh and Tabar (2013) identified the direct and indirect effects of government expenditure in poverty reduction. The direct effects are in the form of benefits received by the poor from government expenditures which takes the form of job creation and welfare programs. The indirect effects emanate from government investments in infrastructures, agriculture, health and education which in turn lead to greater job opportunities and availability of food at a cheaper rate. 


\subsubsection{Agriculture and Poverty Alleviation}

Agriculture can simply be defined as the cultivation of the soil and rearing of animals for the purpose of feeding for survival (Ogboru et al., 2018). Agriculture is a way of life that involves production of animals, fishes, crops, forest resources for the consumption of man and supplying the agro-allied product required by our sectors. It is seen as the inherited and dominant occupation employing about $70 \%$ of Nigerians. Though, subsistence agriculture is practiced in this part of the world, it will not be an exaggeration to say that it is the life-wire of the economies of developing countries. According to Yusuf (2014), the systems of agriculture prevalent in Nigeria comprising of crop production, peasant farming, plantation farming, and mechanized agriculture as its components cannot be overlooked. Government expenditure on agriculture is a mechanism which goes a long way to reduce poverty in every nation. This is obvious in the sense that agriculture helps in sufficient food supply at a very low cost as well as industrial raw materials and also reduce the level of unemployment by creating jobs. Countries that consider investment in agricultural sector as a priority, speedily drive away poverty from their economy because it is a sector that is capable of employing people in mass no matter the age differences and it is highly rewarding both to the government and individual households. It provides foods and income for households while exports of agricultural produce improve a country's balance of payment and increases the GDP growth.

\subsubsection{Education and Poverty Alleviation}

Education can be referred to as change of bad orientation, development of good mindset, forming proper habits and acquiring skill that lead to both human and national development. Educational methods include storytelling, discussion, teaching, training, and directed research. Education is the process of acquiring knowledge, skills, beliefs, values and habits which teach one to be a real human being (Rousseau, 2015). Education helps young people to be focused, independent and possess the ability to motivate themselves. Rousseau (2015) submits that education is a guide to light in the path of our success. Therefore, where proper education is lacking, people tend to be wild and show no concern for the consequences of their actions. Education helps to alleviate poverty in a nation through exposure to opportunities and ability to identify ones potentials. Education helps people to acquire relevant skills and discover their talents and other hidden potentials in them. What makes an individual poor is when he or she does not know what he/she is capable of doing to make a living. Education exposes an individual to opportunities around him or her while the information at his/her disposal provides the empowerment. In line with a popular saying that 'knowledge is power', it also follows that knowledge is acquired through education and a knowledgeable person cannot be poor.

\subsubsection{Health and Poverty Alleviation}

Health care system involves multidimensional facilities, organizations, and trained personnel engaged in providing health care within a geographical area (Business Dictionary, 2018). Health care is the act of taking preventative or necessary medical procedures to improve a person's well-being. This may be done with surgery, the administering of medicine, or other alterations in a person's lifestyle (Business Dictionary, 2018). Health care services are provided through a health care system which comprises hospitals and physicians. Health care system in every nation should include all the activities which promote, restore or maintain the health of the citizenry (World Health Organization, 2018). It takes a healthy workforce to provide services that will keep an economy growing and provide solution to national challenges (Omodero, 2019). The health of people in a nation determine the level of economic growth in that nation, therefore for poverty to be alleviated, there should be an adequate health care services in the country.

\subsubsection{Per Capita Income}

Economic growth is best defined as a long term expansion of productive potential of the economy. The trend of growth could be expanded by raising capital investment spending as a share of national income as well as the size of capital inputs and labour supply, labour force and the technological advancement. Economic growth is the increase of per capita Gross Domestic Product (GDP) or per capita income. According to World Bank (2017) Per Capita GDP is gross domestic product divided by midyear population (that is population as of 1 July for the same year). It means GDP per person. It is an important indicator of economic performance and shows an average living standards and economic wellbeing of a country (Focus Economics, 2017). A rise in per capita GDP signals growth in the economy and tends to reflect an increase in productivity. A higher per capita GDP is equal to a higher standard of living (Investopedia, 2017). The International Monetary Fund (IMF) defines Economic growth as the increase in the inflation-adjusted market value of the goods and services produced by an economy over time. It is conventionally measured as the percentage rate of increase in real gross domestic product, or real GDP, usually in per capita terms (Carreon, 2013). 


\subsection{Theoretical Framework}

Endogenous growth theory pioneered by Romer (1994) is the theory supporting this study. The theory holds that economic growth depends on investment in human capital, innovation and knowledge management (Romer, 1994). Government spending on education (research and development), infrastructures, power and capacity building is very essential, it fosters economic growth and alleviates poverty in a nation. It helps to access a common pool of knowledge emanating from global technological spillovers. Technology is non-rival idea and contagious because its use by one country does not prevent other countries from benefiting from it. This form of government expenditure gives a speedy alleviation of poverty in a country as there will be a trained and productive work force as well as availability of new technologies to increase productivity.

\subsection{Empirical Review}

\subsubsection{Foreign Studies}

Mehmood and Sadiq (2010) employed error correction model to examine the relationship between government expenditure and poverty reduction in Pakistan from 1976 to 2010. The result established the existence of a negative relationship between government expenditure and poverty level in Pakistan. Asghar et al. (2012) also reviewed the impact of government spending on poverty reduction in Pakistan using annual time series data from 1972 to 2008. The study found evidence that government spending on education, to maintain law and order contributed significantly to reduce poverty while expenditures on budget deficit, community and economic services were found to be responsible for poverty in Pakistan. In other words, they had negative contribution to poverty reduction in Pakistan.

Dahmardeh and Tabor (2013) used Autoregressive Distributed Lag (ARDL) technique to study the effects of government expenditure on poverty reduction in Sistan and Baluchestan Province of Iran from 1978 to 2008. The result showed that government constructive expenditures had a positive effect on poverty reduction. Sennoga and Matovu (2013) examined the impact of public spending on economic growth and poverty reduction in Uganda using dynamic computable general equilibrium model. The study found evidence that investments in agriculture and infrastructures contribute to higher economic growth and accelerate the rate of poverty reduction. Kazungu and Cheyo (2014) assessed the impact of government expenditure on growth strategies and poverty reduction in Tanzania and found that government expenditure on social services reduced income poverty indirectly although, the paper stated that the effects could be realized in the long run.

Omari and Muturi (2016) investigated the effect of government sectoral expenditure on poverty level in Kenya using time series data covering a period from 1964 to 2010. The findings from the regression results revealed that expenditures on health and agriculture exerted a significant positive impact on poverty level. The effect of education expenditure was not significant but expenditure on infrastructure had significant negative influence on poverty level. Sasmal and Sasmal (2016) investigated the impact of public expenditure on economic growth and poverty alleviation in India using both fixed and random effects models. The findings disclosed that public expenditure on infrastructures such as road, power, irrigation, transport and communication was high as well as the per capita income and so the effect on poverty reduction was significant and positive.

Fosu (2017) provided a comparative global evidence on the enhancement of economic growth through poverty reduction in the developing countries with emphasis on the role of income inequality. The study discovered that high initial levels of inequality impede the effectiveness of growth in reducing poverty while growth inequality increases poverty directly at a given level of growth. Anderson et al. (2018) employed meta-regression to analyze the relationship between government spending and income poverty of the low and middle income countries. The study generally established that higher government spending did not play any significant role in income poverty reduction of the low and middle income countries under review. Asadullah and Savoia (2018) assessed the global adoption of MDGs and state capacity using cross-section and panel data of 89 developing economies from 1990 to 2013. The study found that poverty reduced faster in countries that initially had higher income poverty. This result suggested that MDGs adoption is highly instrumental to poverty alleviation in the developing countries.

Maros and Will (2018) examined the impact of productivity improvements in agriculture, industry and service for global poverty reduction. The study discovered that increases in agricultural productivity were more effective in reducing poverty in poor countries than increases in industry and services. Sasana and Kusuma (2018) made use of multiple fixed-effects model (FEM) to analyze the effect of government expenditure on poverty reduction in Indonesia from 2008 to 2013. The study covered 33 Provinces in Indonesia and the factor that influence poverty level were divided into economic factors and government outcome. Generally, the study found that economic factors 
had positive impact on poverty reduction in Indonesia while government outcome which includes government spending had a significant negative effect on poverty level.

\subsubsection{Domestic Studies}

Olabode (2012) used Dynamic Ordinary Least Squares (DOLS) method to examine the effect of defense expenditure on poverty reduction in Nigeria. The study provided evidence that defense expenditure which are in different categories had positive relationship with poverty indicator. However, military expenditure, secondary school enrolment and output per capita had negative relationship with poverty level. Enyim (2013) employed ordinary least squares method and a data covering a period from 1980 to 2009 to analyze the impact of government spending on poverty reduction in Nigeria. The regression results showed that government expenditure had a significant positive impact on poverty reduction in Nigeria.

Nwosa (2014) made use of annual time series data covering a period from 1981 to 2011 and ordinary least squares method to examine the impact of government expenditure on unemployment and poverty rates in Nigeria. The study discovered that government expenditure had a significant positive impact on unemployment rate while on poverty rate, insignificant negative impact was established. Odior (2014) examined the probable implication of government expenditure policies on education and poverty reduction Nigeria following the need to attain the Millennium Development Goals (MDGs) by the United Nations. Based on the findings of this study, it was predicted that MDGs might be far reaching in terms of improvement in education and reduction in poverty in the country. Thus, the study suggested more allocation of funds to educational sector in order to attain Millennium Development Goals.

Sunkanmi and Abayomi (2014) investigated the relationship between government expenditure and poverty level in Nigeria using Keynesian macroeconomic framework which assumes that any increase in government expenditure affects economic growth positively. The findings revealed that foreign aid, savings and power generation were all insignificant in reducing poverty level in the country. Adelowokan and Osoba (2015) used ordinary least squares method and granger causality test to assess the role of oil revenue and government spending in reducing poverty rate in Nigeria from 1970 to 2013 . The study found evidence that oil revenue and GDP exerted negative effects on poverty rate within the period being investigated.

Asimiyu and Saidi (2015) examined the impact of public budget indicators such as federally collected government revenue and aggregate expenditure on the poverty level in Nigeria using annual time series data covering a period from 1980 to 2013. The study discovered that federally collected government revenue and aggregate expenditure increased poverty rate in Nigeria. The negative outcome of the study was associated with undue dependence of the economy on oil revenue, high rate of corruption and poor budget processes and implementation. The study suggested budget restructuring which should be based on people's preferences. Owuru and Farayibi (2016) used fiscal policy measures to address the issue of poverty reduction in Nigeria from 1980 to 2011. The findings revealed that the level of government capital investments in Nigeria could not alleviate poverty within the period covered by the study.

Oriavwote and Ukawe (2018) studied the effect of government expenditure on poverty reduction in Nigeria. The study covered a period from 1980 to 2016 and made use of ordinary least squares technique and other statistical tools for analysis. Based on the regression results, government expenditure on education and health had significant and positive impact on per capita income (PCI). Similarly, the result also showed that government expenditure on building and construction equally had a significant and positive effect on PCI. Despite the outcome of this study, the scourge of poverty and unemployment in Nigeria is such that government sectoral spending is not physically felt by the citizens. That means, there is a contradiction between this study and the physical evidences of the relationship between government expenditure and poverty reduction in the country.

Ogboru et al. (2018) assessed the government expenditure on agriculture and its impact on unemployment reduction in Nigeria from 1999 to 2015. The study provided a statistical evidence that government expenditure did not reduce unemployment rate within the period covered by the study. Omodero (2019) employed ordinary least squares technique to investigate the effect of government general spending on human capital development which most importantly involves the education and health care of the entire country's work force for proper economic growth and development. The study covered a period from 2003 to 2017 and the findings indicated that government capital expenditure had an insignificant negative impact on human capital development while the recurrent expenditure impacted on human development index positively and significantly. Thus, the study suggested that more government capital investment on the nation's human capacity building is necessary for better productivity and growth in the country. 


\subsection{Research Gap}

Many foreign and local studies have been reviewed in this study, however following the MDGs, the current study takes a millennium approach by using data from 2000 to 2017 to actually assess the effect of MDGs influence on government sectoral expenditure target in affecting poverty reduction. The key sectors that can enhance poverty alleviation in Nigeria if appropriately financed are included in this study and per capita income used as the response variable is a variable that accurately reflects the standard of living in an economy. The per capita income is an income per person in a country, though it is alleged that about 87 million Nigerians live on less than 1.90USD per day. However, this study provides an empirical evidence on the effect of government spending in reducing poverty through concentration on the key sectors of the economy.

\section{Methodology}

\subsection{Research Design}

This study made use of quasi-experimental design in order to realize the purposes of the study. Here the research adopted the econometric analysis techniques of ordinary least squares (OLS) multiple regression technique. This research design is necessary because the selected research area for investigation is empirical, quantitative and analytical in nature where the response and explanatory variables are perceived over a time frame for any variation that can possibly occur.

\subsection{Types and Sources of Data Collection}

The study made use of secondary form of data because the research work is analytical in nature. Time series data relating to the dependent and explanatory variables used covered a period from 2000 to 2017. All the data employed in this study were obtained from the Central Bank of Nigeria Statistical Bulletin, 2017 edition with the exception PCI which was collected from the World Bank. All the data were expressed in Billions of Naira (Nigerian local currency).

\subsection{Model Specification}

The functional and econometric relationship between the dependent variable and the independent variables are seen in the equation below:

$$
\begin{gathered}
\text { PCI }=\mathrm{f}(\mathrm{AGR}, \mathrm{BCS}, \mathrm{EDU}, \mathrm{HLT}) \\
\mathrm{PCI}=\beta_{0}+\beta_{1} \mathrm{AGR}+\beta_{2} \mathrm{BCS}+\beta_{3} \mathrm{EDU}+\beta_{4} \mathrm{HLT}+\mu
\end{gathered}
$$

Where:

$\mathrm{PCI}=$ Per Capita Income; AGR = Agriculture; BCS = Building and Construction; EDU = Education; $\beta_{0}=$ Constant; $\beta_{1}-\beta_{4}=$ Regression coefficients; $\mu=$ Error term.

On the a priori, we expect; $\beta_{1}>0, \beta_{2}>0, \beta_{3}>0, \beta_{4}>0$. 


\section{Data Analysis and Interpretations}

\subsection{Trend Analysis and Interpretation}
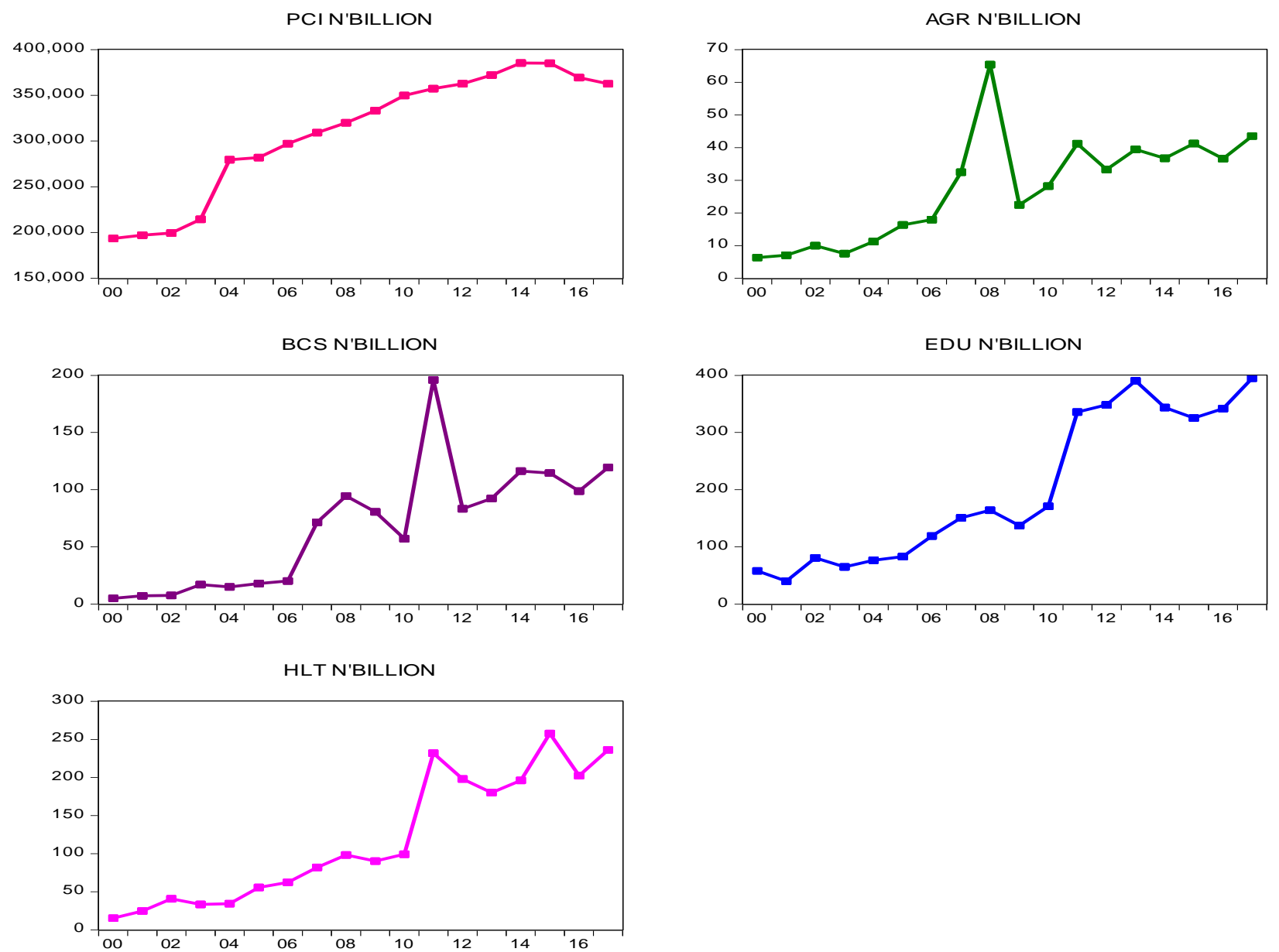

Figure 2. Trend of PCI, AGR, BCS, EDU and HLT from 2000-2017

Source of data: World Bank and Central Bank of Nigeria.

From Figure 2 above, a little decline in PCI could be observed while all the independent variables were rising and falling but one obvious thing was the sharp increases in agriculture in 2008, building and construction in 2011 and education in 2013. This suggests that every administration in Nigeria has its own area of interest and pursues it vigorously without following the law of equilibrium or application of a mathematical formula of balancing an equation. If government expenditure is not significantly felt in all the sectors of an economy, there is no way poverty could be eradicated because every facet of the economy is relevant and contributes to the well-being of the country.

\subsection{Regression Results and Interpretations}

Table 1. Model summary

\begin{tabular}{lccccc}
\hline Model & R & R Square & Adjusted R Square & Std. Error of the Estimate & Durbin-Watson \\
\hline 1 & .897 & .804 & .743 & 34374.58052 & 1.233
\end{tabular}

a. Predictors: (Constant), HLT, AGR, BCS, EDU

b. Dependent Variable: PCI

Source: Author's computation, 2019. 
Table 1 above reveals the model summary of the regression results. The value of $\mathrm{R}$ (which indicates the relationship between the dependent variable and the independent variables) is $89.7 \%$ showing a strong association between PCI and government expenditure on agricultural sector, building and construction, educational sector and health sector. This relationship implies that government expenditure on these key sectors has the potential to alleviate poverty in Nigeria. Similarly, the coefficient of determination which is the R Square is $80.4 \%$. This value shows the extent to which AGR, BCS, EDU and HLT explain the variations in PCI, thus, it is only the remaining $19.6 \%$ that other factors not related with the model can account for. However, the Durbin-Watson is within the area that does not provide reason for enquiry.

Table 2. ANOVA

\begin{tabular}{ccccccc}
\hline \multicolumn{1}{c}{ Model } & Sum of Squares & Df & Mean Square & F & Sig. \\
\hline \multirow{3}{*}{1} & Regression & 62934525295.163 & 4 & 15733631323.791 & 13.315 & $.000 *$ \\
& Residual & 15360953218.113 & 13 & 1181611786.009 & & \\
& Total & 78295478513.276 & 17 & & & \\
\hline
\end{tabular}

a. Dependent Variable: PCI

b. Predictors: (Constant), HLT, AGR, BCS, EDU

$*$ Significant at $1 \%$.

Source: Author's computation, 2019.

From Table 2 above, the F-Statistic has the value of 13.315 and the p-value is $0.000<0.05$ level of significance. This implies that all the independent variables jointly influence PCI and the model is appropriate for the study.

Table 3. Coefficients

\begin{tabular}{|c|c|c|c|c|c|c|c|c|}
\hline & \multirow[t]{2}{*}{ Model } & \multicolumn{2}{|c|}{ Unstandardized Coefficients } & \multirow{2}{*}{$\begin{array}{c}\begin{array}{c}\text { Standardized } \\
\text { Coefficients }\end{array} \\
\text { Beta }\end{array}$} & \multirow[t]{2}{*}{$\mathrm{T}$} & \multirow[t]{2}{*}{ Sig. } & \multirow{2}{*}{$\begin{array}{c}\begin{array}{c}\text { Significance } \\
\text { level }\end{array} \\
5 \%\end{array}$} & \multirow[t]{2}{*}{ Remarks } \\
\hline & & $\bar{B}$ & Std. Error & & & & & \\
\hline \multirow{5}{*}{1} & (Constant) & 209080.897 & 17333.183 & & 12.062 & .000 & & \\
\hline & AGR & 1224.818 & 877.005 & .294 & 1.397 & .186 & $>0.05$ & $\begin{array}{c}\text { NO } \\
\text { IMPACT }\end{array}$ \\
\hline & BCS & 16.356 & 397.305 & .013 & .041 & .968 & $>0.05$ & $\begin{array}{c}\text { NO } \\
\text { IMPACT }\end{array}$ \\
\hline & EDU & 172.908 & 240.359 & .335 & .719 & .485 & $>0.05$ & $\begin{array}{c}\text { NO } \\
\text { IMPACT }\end{array}$ \\
\hline & HLT & 257.515 & 442.665 & .318 & .582 & .571 & $>0.05$ & $\begin{array}{c}\text { NO } \\
\text { IMPACT }\end{array}$ \\
\hline
\end{tabular}

a. Dependent Variable: PCI

Source: Author's computation, 2019.

Table 3 shows the individual results of the independent variables and their respective effects on PCI. The results confirm that their p-values are greater than 5\% level of significance, meaning that, all the independent variables do not have any significant impact on PCI. The implication of this result is that government expenditure on AGR, BCS, EDU and HLT are not adequate and cannot alleviate poverty in Nigeria. Although there are other qualitative factors militating against poverty alleviation and eradication in Nigeria but this statistical evidence shows that government spending on these key sectors used in this study does not exert sufficient influence on poverty reduction in the country. 


\section{Conclusion and Recommendations}

\subsection{Conclusion}

This study concludes that the MDGs on poverty alleviation that could not be achieved in 2015 is still not possible if government expenditure on the key economic sectors is not improved. There is need for more funds to be budgeted for agricultural, educational and health sectors as well as for building and construction. The concept of government spending and endogenous growth theory jointly posit that public expenditure on education, health services, innovations in agriculture and other technologies help economic growth and poverty alleviation in every given economy.

\subsection{Recommendations}

- Therefore government should embark on poverty alleviation by providing infrastructures in the rural areas and not only in the city. Adequate infrastructures will boost agriculture and the per capita income of the country because enough jobs will be created and the jobless youths will find employment.

- Investment in the education of Nigerians is highly recommended, scholarships should be provided and be made accessible to the poor and not a scenario where the rich still use their position to highjack the scholarship opportunities for their children and family members.

- Construction of roads, bridges, railways, markets and buildings will help to alleviate poverty in Nigeria. Good roads enhance the smooth running of businesses and as a result people can freely travel to the interior villages and move the agricultural produce to the urban areas where there is sufficient market for it.

- Hospitals and health centers are recommended especially for the poor who cannot afford the cost of using private hospitals. The government should work with Non-governmental Organizations whose targets are to reach out to the poor especially in the area of providing health care services.

\section{Acknowledgements}

The author thanks the anonymous reviewers and editors of Research in World Economy for their invaluable input and comments that enriched the quality of this paper.

\section{References}

Adebayo, B. (2018). Nigeria overtakes India in extreme poverty ranking. CNN. Retrieved March 27, 2019, from https://edition.cnn.com/2018/06/26/africa/nigeria-overtakes-india-extreme-poverty-intl/index.html

Adelowokan, O.A., \& Osoba, A.M. (2015). Oil revenue, government expenditure and poverty rate in Nigeria. Global Journal of Management and Business Research: B Economics and Commerce, 15(10), 11-20.

Anderson, E., D’Orey, M.A.J., Duvendack, M., \& Esposito, L. (2018). Does government spending Affect income poverty? A meta-regression analysis. World Development, 103(2018), 60-71. https://doi.org/10.1016/j.worlddev.2017.10.006

Asadullah, M.N., \& Savoia, A. (2018). Poverty reduction during 1990-2013: Did millennium Development goals adoption and state capacity matter?. World Development, 105(2018), 70-82. https://doi.org/10.1016/j.worlddev.2017.12.010

Asghar, N., Hussain, Z., \& Rehman, H.U. (2012). The impact of government spending on poverty Reduction: Evidence from Pakistan 1972 to 2008. African Journal of Business Management, 6(3), 845-853. https://doi.org/10.5897/AJBM11.922

Asimiyu, G.A., \& Saidi, A.M. (2015). Impact assessment of public budget indicators on the Nigerian poor. Journal of Economics and Development Studies, 3(3), 71-85. https://doi.org/10.15640/jeds.v3n3a7

Atiku, A. (2018). In 2018, Nigeria became world headquarters for extreme poverty-Atiku. PM News. Retrieved March 27, 2019, from https://www.pmnewsnigeria.com/2018/12/31/in-2018-nigeria-became-world-headquarters-for-extreme-povertyatiku/

Business Dictionary. (2018). What is health care?. Retrieved November 22, 2018, from www.businessdictionary.com

Carreon, M.A. (2013). Youth Unemployment Analysis. Mexican Institute of Youth (IMJUVE). Retrieved July 18, 2014 ,

from 
http://www.youtheconomicopportunities.org/sites/default/files/uploads/resource/Miguel\%20Angel\%20Carreon. pdf

Dahmardeh, N., \& Tabar, M.H. (2013). Government expenditures and its impact on poverty Reduction (Empirical from Sistan and Baluchestan Province of Iran). International Journal of Academic Research in Economics and Management Sciences, 2(1), 251-260.

Enyim, O.B. (2013). Government spending and poverty reduction in Nigeria's economic growth. International Journal of Social Sciences and Humanities Reviews, 4(1), 103-115.

Everett, R. W. (2011). Economic Forecasting. Encyclopedia Britannica Ultimate Reference Suite. Chicago: Encyclopedia Britannica.

Focus Economics. (2017). What is GDP per capita? Retrieved January 2, 2018, from https://www.focus.economics.com/

Fosu, A.K. (2017). Growth, inequality and poverty reduction in developing countries: Recent Global evidence. Research in Economics, 71(2017), 306-336. http://dx.doi.org/10.1016/j.rie.2016.05.005

Investopedia (2019). Per Capita Income (PCI). Investopedia, LLC. Retrieved March 28, 2019, from https://www.investopedia.com/

Kazeem, Y. (2018). Nigeria has become the poverty capital of the world. Quartz Africa. Retrieved March 27, 2019, from https://qz.com/africa/1313380/nigerias-has-the-highest-rate-of-extreme-poverty-globally/

Kazungu, K.G.M., \& Cheyo, M.B. (2014). Government expenditure on growth strategies and Poverty reduction in Tanzania. What have we learned?. African Journal of Economic Review, 11(1), 38-47.

Maros, I., \& Will, M. (2018). Sectoral productivity growth and poverty reduction: National and Global impacts. World Development, 109(2018), 429-439. http://dx.doi.org/10.1016/j.worlddev.2017.07.004

Mehmood, R., \& Sadiq, S. (2010). The relationship between government expenditure and poverty: A co-integration analysis. Romanian Journal of Fiscal Policy, 1(1), 29-37.

Nwosa, P.I. (2014). Government expenditure, unemployment and poverty rates in Nigeria. JORIND, 12(1), 77-84.

Odior, E.S.O. (2014). Government expenditure on education and poverty reduction: Implications for achieving the MDGs in Nigeria. A computable general equilibrium micro-simulation analysis. Asian Economic and Financial Review, 4(2), 150-172.

Ogba, L. (2011). Elements of public finance (2nd ed.) Heritage Publications, Nigeria.

Ogboru, I., Abdulmalik, F.A., \& Park, I.O. (2018). Government expenditure on agriculture and its Impact on unemployment reduction in Nigeria: 1999-2015. International Journal of Economics, Commerce and Management, 6(3), 1-25.

Olabode, P.O. (2012). Defense spending and poverty reduction in Nigeria. American Journal of Economics, 2(6), 122-127. https://doi.org/10.5923/j.economics.20120206.05

Omari, L.V., \& Muturi, W. (2016). The effect of government sectoral expenditure on poverty level in Kenya. Global Journal of Human-Social Science: E Economics, 16(2), 1-11.

Omodero, C.O. (2019). Government general spending and human development: A case study of Nigeria. Academic Journal of Interdisciplinary Studies, 8(1), 51-60. https://doi.org/10.2478/ajis-2019-0006

Omodero, C.O., \& Dandago, K.I. (2019). Tax revenue and public service delivery: Evidence From Nigeria. International Journal of Financial Research, 10(2), 82-91. https://doi.org/10.5430/ijfr.v10n2p82

Oriavwote, V.E., \& Ukawe, A. (2018). Government expenditure and poverty reduction in Nigeria. Journal of Economics and Public Finance, 4(2), 156-163. https://10.22158/jepf.v4n2p156.

Owuru, J.E., \& Farayibi, A.O. (2016). Examining the fiscal policy-poverty reduction nexus in Nigeria. Munich Personal RePEc Archive. Retrieved from https://mpra.ub.uni-muechen.de/741841

Romer, P.M. (1994). The origins of Endogenous Growth. The Journal of Economic Perspectives, 8(1), 3-22. JSTOR.

Rousseau, J.J. (2015). What is Education?. Retrieved November 22, 2018, from https://www.quora.com

Sanusi, L. (2018). Nigeria is world's poverty headquarters, says Sanusi. The Nation. Retrieved March 27, 2019, from http://thenationonlineng.net/nigeria-worlds-poverty-headquarters-says-sanusi/ 
Sasana, H., \& Kusuma, P. (2018). Government expenditure and poverty in Indonesia. International Conference on Economics, Business and Economic Education 2018, KnE Social Sciences, Pages 142-153. https://doi.org/10.18502/kss.v3i10.3125.

Sasmal, R., \& Sasmal, J. (2016) Public expenditure, economic growth and poverty alleviation. International Journal of Social Economics, 43(6), 604-618. https://doi.org/10.1108/IJSE-08-2014-0161

Sennoga, E.B., \& Matovu, J.M. (2013). Public spending composition in Uganda and its implication for growth and poverty reduction. Public Finance Review, 41(2), 227-247. https://doi.org/10.1177/1091142112448412

Sunkanmi, O.A., \& Abayomi, O.O. (2014). Testing public expenditure and poverty reduction Nexus in Nigeria. Developing Country Studies, 4(6), 116-123.

UNDESA. (2015). The millennium development goals report 2015. New York: United Nations. Retrieved March 28, 2019, from http://www.un.org/millenniumgoals/reports.shtml

Wilhelm, V., \& Fiestas, I. (2005). Exploring the link between public spending and poverty Reduction: Lessons from the 90s. Working Papers. World Bank Institute Washington, D.C.

World Bank. (2017). Nigeria: Gross Domestic Product per Capita (Constant LCU). Retrieved from https://data.worldbank.org/indicator/NY.GDP.PCAP.KN?view=chart.

World Health Organization. (2018). Health System. Retrieved March 27, 2019, from http://www.wpro.who.int/chips/chip04/definitions.htm

Yusuf, S.A. (2014). Role of Agriculture in Economic Growth \& Development: Nigerian Perspective. Munich Personal RePEc Archive Paper 55536; 1-22. University of Lagos, Akoka, Nigeria. 